\title{
Profile of Rapid Molecular Test of Tuberculosis Using Xpert MTB/RIF
}

\author{
Faigah Aprilia Sy Faraid ${ }^{1}$, Irda Handayani ${ }^{1}$, Tenri Esa ${ }^{2}$ \\ ${ }^{1}$ Department of Clinical Pathology, Faculty of Medicine,Hasanuddin University/Dr.Wahidin Sudirohusodo Hospital, Makassar, Indonesia. \\ E-mail: faigahaprilia@yahoo.com \\ 2 Department of Clinical Pathology, Faculty of Medicine, Hasanuddin University/Dr.Wahidin Sudirohusodo Hospital, Makassar/Dadi \\ Hospital, Makassar, Indonesia
}

\begin{abstract}
Tuberculosis (TB) ranked the $10^{\text {th }}$ highest cause of death in the world in 2016 according to the World Health Organization (WHO). To date, TB remains a top priority and is one of the goals in Sustainability Development Goals (SDGs), suggesting an urgent need of rapid detection methods for proper diagnosis and treatment. Rapid molecular test using Xpert MTB/RIF is one of the detection methods for TB diagnosis and it is expected to be able to early detect TB cases and anti-tuberculosis drug resistance. The purpose of this study was to determine the profile of rapid molecular test of tuberculosis using Xpert MTB/RIF device in the period of September 2017-August 2018 at Dr. Wahidin Sudirohusodo Hospital, Makassar. This study was retrospective research with a cross-sectional method using secondary data of rapid molecular test of Xpert MTB/RIF in the period of September 2017-August 2018. Data were statistically analyzed using SPSS version 22 and Chi-Square test with a significance value of 0.05 . From 527 sputum samples, $96.8 \%$ adult TB was predominantly found. The "MTB not detected", "MTB detected" , and "MTB detected with Rif resistance" result was predominantly found in the 74.6\% TB non-HIV group; 42.4\% TB-HIV group, and 3.8\% non-HIV TB group. There were remarkably higher number of "MTB not detected" results of rapid molecular tests using Xpert MTB/RIF device in the group of pediatric and adult TB. The proportion of "MTB not detected" was higher in the TB-non-HIV group; while the "MTB detected, Rif-sensitive" was higher in the TB-HIV group and the "MTB detected, Rif-resistance" was higher in the TB-non-HIV group. It was recommended to carry out further research by performing diagnostic tests consisting of Acid-Fast Bacilli, rapid molecular test with Xpert MTB/RIF, and MTB culture.
\end{abstract}

Keywords: Tuberculosis, rapid molecular test, Xpert MTB/RIF device

\section{INTRODUCTION}

Tuberculosis (TB) is a communicable disease caused by a bacterium from the Mycobacterium genus known as Mycobacterium tuberculosis (MTB), with the ability to target various organs, especially the lungs. Tuberculosis ranked the $10^{\text {th }}$ highest cause of death worldwide in 2016, according to a World Health Organization (WHO) report. Therefore, TB remains a top priority in the world and it is one of the goals in Sustainability Development Goals (SDGs) ${ }^{1-3}$

In 2016 there were 10.4 million TB cases globally (CI 8.8 million - 12 million) which is equivalent to 120 cases per 100,000 populations. According to World Health Organization (WHO) Global Tuberculosis Report 2016, Indonesia ranked the second highest TB burden in the world. Based on the 2017 WHO report, it was estimated that $1,020,000$ cases were found in Indonesia, but only 420,000 cases have been reported to the Ministry of Health. In addition, the
World Health Organization estimated that there were 32,000 cases of Multi-Drug Resistance (MDR) in Indonesia. ${ }^{1-4}$

Tuberculosis is one of the deathly diseases which lacks effective detection methods. One of the priorities in TB control in Indonesia is the finding of early detection method, microscopic examination of Acid-Fast Bacilli (AFB) which is frequently associated with Human Immunodeficiency Virus (HIV), and a need to improve laboratory capacity to diagnose Multi-Drug Resistant TB (MDR-TB).,2,4

Since 2010, WHO has recommended the use of the Xpert MTB/RIF device as a preliminary examination for the diagnosis of MDR-TB and HIV-TB. Xpert MTB/RIF examination is a molecular-based assay with Nucleic Acid Amplification Technology (NAAT) which is able to diagnose TB and its resistance to Rifampicin within two hours. One attempt to overcome these problems is the establishment of TB diagnosis using the rapid 
molecular test using Xpert MTB/RIF based on the Regulation of the Ministry of Health, Indonesia, number 67 of 2016. Detection of TB using rapid molecular test Xpert MTB/RIF has expanded its use not only to find MDR-TB (high risk) and TB in people with HIV AIDS (PLWHA) but are also used to assist the diagnosis of new TB cases in general (low risk). ${ }^{1-8}$

Several studies have shown that Xpert MTB/RIF is a recommended method for TB routine diagnosis with sensitivity and specificity of $93 \%$ and $98.3 \%$ respectively because it accelerates the management of patients with suspected TB. ${ }^{9}$ From financial perspective, this recommendation is in line with WHO policy guidelines. ${ }^{10}$ Results of large-scale studies showed that rapid molecular test with Xpert MTB/RIF had a relatively better sensitivity and specificity for TB diagnosis compared to microscopic examination and its quality of results were nearly as good as that of bacterial culture. . $9,10^{2}$

Based on the description above, the purpose of the study was to determine the profile of the results of a rapid molecular tests using Xpert MTB/RIF in non-HIV-TB and TB-HIV patients at Dr. Wahidin Sudirohusodo Hospital, Makassar in the period of September 2017 to August 2018.

\section{METHODS}

This research was retrospective research with a cross-sectional design using secondary data from the results of rapid molecular test Xpert MTB/RIF in the period of September 2017 to August 2018 at the Medical Record Installation of Dr. Wahidin Sudirohusodo Hospital, Makassar. The accessible population was all TB patients in Dr. Wahidin Sudirohusodo Hospital, Makassar for the period of September 2017-August 2018. The study used sputum, bronchial wash, stomach wash, and cerebrospinal fluid of all TB patients who met the inclusion criteria.

The inclusion criteria were non-HIV adult and pediatric patients who had previously been diagnosed with TB by clinicians had results of rapid molecular test and anti-HIV Immunochromatographic test (ICT) or non-reactive result of Enzyme-Linked Immunosorbent Assay (ELISA). Adult and pediatric TB patients involved in this study were $\geq 18$ and $0-14$ years, respectively. Tuberculosis patients with medical record data but incomplete laboratory test were excluded.

The data were analyzed using descriptive statistical test with SPSS ver.22. Statistical analysis was based on the calculation of frequency distribution and Chi-Square tests with a significance value of 0.05 . This study was approved by the Health Research Ethics Committee of the Faculty of Medicine, Hasanuddin University/Dr. Wahidin Sudirohusodo Hospital, Makassar with number 598/H4.8.4.5.31/PP-36-KOMETIK/2018.

\section{RESULTS AND DISCUSSIONS}

The study was carried out by using secondary data of rapid molecular tests using Xpert MTB/RIF at Dr. Wahidin Sudirohusodo Hospital, Makassar in the period of September 2017-August 2018. A total of 533 data were obtained with the characteristics presented in Table 1.

Invalid results were found in some samples, possibly due to improper processing of sample caused by interference during the Polymerase Chain Reaction (PCR) process. In addition, Error results were obtained due to the possible failure of the component during the PCR process, leading to the inability to detect MTB and the undetermined results. In both cases, rapid molecular test using Xpert MTB/RIF must be repeated. To meet the statistical test requirements, subjects with Intermediate, Error and No Result of RIF resistance were excluded from the further analysis due to a few number of the samples (only two people of each category). Therefore, the remaining samples for analysis were 527.

It was shown in Table 1 that among 527 patients there were 331 men (62.1\%) and 516 sputum samples $(96.8 \%)$ with a higher percentage of positive MTB results were also found in sputum samples. Based on the distribution of age, 516 adult TB patients were found (96.8\%). Based on the type of TB, 473 (88.7\%) non-HIV TB patients were found. In addition, the results of rapid molecular tests using Xpert MTB/RIF were dominated by 381 (71.5\%) MTB not detected result (Table 1 ).

Table 2 shows that 15 (88.2\%) and 366 (71.8\%) results of "MTB not detected" were found among the children TB andthe adult TB patients, respectively. Statistical analysis using Chi-Square test found no significant differences in the results of rapid molecular tests using Xpert MTB/RIF between pediatric and adult TB $(p=0.306)$.

Table 3 shows a significant difference in the distribution of test results using Xpert MTB/RIF between positive HIV and non-HIV-TB patients $(p=0.002)$. Results of "MTB not detected" were predominantly found in non-HIV-TB (74.6\%) compared to HIV-TB (54.2\%) patients. Contrasting, 
Table 1. Characteristic of rapid molecular test results using Xpert MTB/RIF $(n=533)$

\begin{tabular}{llcc}
\hline & Variable & $\mathbf{n}$ & \% \\
\hline \multirow{2}{*}{ Samples } & Sputum & 516 & 96.8 \\
& Bronchial wash & 15 & 2.8 \\
& Stomach wash & 1 & 0.2 \\
& Cerebrospinal fluid & 1 & 0.2 \\
\multirow{2}{*}{ Age groups } & Pediatric & 17 & 3.2 \\
& Adult & 516 & 96.8 \\
Sex & Male & 331 & 62.1 \\
& Female & 202 & 37.9 \\
TB & HIV & 60 & 11.3 \\
& Non-HIV & 473 & 88.7 \\
& Negative & 385 & 72.2 \\
& Positive & 148 & 27.8 \\
& MTB not detected & 381 & 71.5 \\
& MTB detected;Rif sensitive & 126 & 23.6 \\
& MTB detected;Rif resistant & 20 & 3.8 \\
& MTB detected;Rif intermediate & 2 & 0.4 \\
& Error & 2 & 0.4 \\
& No result & 2 & 0.4 \\
\hline
\end{tabular}

Source: Secondary data

Table 2. Results of rapid molecular test using Xpert MTB/RIF based on age category

\begin{tabular}{|c|c|c|c|c|c|}
\hline \multirow{2}{*}{ Age group } & \multicolumn{3}{|c|}{ Result of Rapid Molecular Test Using Xpert MTB/RIF } & \multirow{2}{*}{$\begin{array}{l}\text { Total } \\
\text { n (\%) }\end{array}$} & \multirow{2}{*}{ p-value } \\
\hline & $\begin{array}{c}\text { MTB not detected } \\
\text { n (\%) }\end{array}$ & $\begin{array}{c}\text { MTB detected; } \\
\text { Rif sensitive } n(\%)\end{array}$ & $\begin{array}{l}\text { MTB detected; Rif } \\
\text { resistant n (\%) }\end{array}$ & & \\
\hline Pediatric & $15(88.2)$ & $2(11.8)$ & $0(0.0)$ & $17(100)$ & \\
\hline Adult & $366(71.8)$ & $124(24.3)$ & $20(3.9)$ & $510(100)$ & 0.306 \\
\hline Total & $381(72.3)$ & $126(23.9)$ & $20(3.8)$ & $527(100)$ & \\
\hline
\end{tabular}

Source: Secondary data

Table 3. Results of rapid molecular test using Xpert MTB/RIF in TB -HIV and non-HIV-TB patients

\begin{tabular}{|c|c|c|c|c|c|}
\hline \multirow[b]{2}{*}{ Category of TB } & \multicolumn{3}{|c|}{ Results of Rapid Molecular Test Using Xpert MTB/RIF } & \multirow{2}{*}{$\begin{array}{l}\text { Total } \\
\text { n (\%) }\end{array}$} & \multirow[b]{2}{*}{ p-value } \\
\hline & $\begin{array}{c}\text { MTB not detected } \\
\text { n (\%) }\end{array}$ & $\begin{array}{c}\text { MTB detected; } \\
\text { Rif sensitive n (\%) }\end{array}$ & $\begin{array}{c}\text { MTB detected; } \\
\text { Rif resistance } n(\%)\end{array}$ & & \\
\hline HIV-TB & $32(54.2)$ & $25(42.4)$ & $2(3.4)$ & $59(100)$ & \\
\hline Non-HIV-TB & $349(74.6)$ & $101(21.6)$ & $18(3.8)$ & $468(100)$ & 0.002 \\
\hline Total & $381(72.3)$ & $126(23.9)$ & $20(3.8)$ & $527(100)$ & \\
\hline
\end{tabular}

Source: Secondary data

results of "MTB detected; Rif sensitive" were predominantly found HIV-TB (42.4\%) compared to non-HIV TB patients (21.6\%).

This study showed that TB was more prevalent in 331 (62.1\%) males compared to 202 (37.9\%) females. This was in line with TB data in Indonesia showing total 420,994 TB cases in 2017 (accessed on May 17, 2018). Based on the gender, the number of new TB cases in 2017 were 1.4 times greater in males than in females. ${ }^{4}$

Based on the previous survey on tuberculosis prevalence, the prevalence of TB in male was three times higher than in female, similar to data in other countries. This was possibly because male are generally more exposed to TB risk factors such as smoking and lack of compliance with taking medication. This survey found that $68.5 \%$ male and $3.7 \%$ female participants were active smokers. ${ }^{4}$ 
Table 2 shows that 15 results (88.2\%) of "MTB not detected" were obtained in pediatric TB patients, possibly due to TB-unspecific clinical symptoms that resembled the clinical symptoms of other diseases. In general, the diagnosis of TB in children is made based on four things: bacteriological culture of TB, TB-specific clinical symptoms, evidence of TB infection (positive tuberculin test or close contact with TB patients) and chest X-ray findings. ${ }^{11,12}$

Bacteriological culture remains the main laboratory test for confirmation of TB in children. Difficulties of sputum collection in children and the nature of paucibacillary in pediatric $T B$, leading to difficulty of TB diagnosis based on bacteriological culture. This was supported by a meta-analysis of 15 studies in 2015 by Detjen et al. who reported a 62\% lower sensitivity of Xpert MTB/RIF found in children $<15$ years. The minimum number of bacilli that can be detected by rapid molecular test using Xpert MTB/RIF were 131 colony-forming units per $\mathrm{mL}$ of sputum. The paucibacillary nature of the pediatric sample partly explains the lower sensitivity of rapid molecular test using Xpert MTB/RIF. ${ }^{13-15}$

The results of rapid molecular tests using Xpert MTB/RIF in the adult TB were dominated by 366 (71.8\%) "MTB not detected" , suggesting a multifactorial cause and a need to reevaluate the initial diagnosis. Pulmonary TB is relatively easy to be recognizedfrom its clinical manifestations, symptoms, physical examination, radiological features, and bacteriological culture. However, it is not always practically easy to make the diagnosis. Several differential diagnosis of TB such as Bacterial pneumonia, Mycoplasmal pneumonia, Bronchogenic carcinoma, Brucellosis, Hodgkin's lymphoma, and Sarcoidosis havesimilar clinical manifestations such as cough with purulent sputum, hematoma, spasms, night sweats, anorexia, malaise, and chest pain. ${ }^{16,17}$

According to the American Thoracic Society (ATS) and WHO 1964, the definitive diagnosis of pulmonary TB is the finding of MTB in sputum or lung tissue in culture, but not all of them shows positive results in sputum slides or cultures because lung abnormalities which are not related to the bronchi or patients cannot cough up sputum well; therefore, the diagnosis of pulmonary TB is mostly merely based on clinical or radiological abnormalities. This is numerously reported and resulted in "Not detected" results of rapid molecular test using Xpert MTB/RIF. ${ }^{16-18}$

The medical record of previous consumption of
anti-TB drug was important in this study because patients with a history of anti-TB drug may experience improvement in clinical symptoms, which can affect the production and quality of sputum and the number of MTB. Therefore, treatment history in TB patients is very important to rule out false negatives. ${ }^{17}$

Samples used for the rapid molecular test using Xpert MTB/RIF must be ensured the quality in accordance with the laboratory standards. Detection of the complex MTB is influenced by the number of microorganisms in the specimen. This should be confirmed by the use of sputum to detect TB depending on the quality of the specimen used. An individual with a result of "MTB not detected" of rapid molecular test using Xpert MTB/RIF examination does not $100 \%$ rule out TB diagnosis and thus requires further clinical management and other diagnostic tests including repeated test of Xpert MTB/RIF using different sputum specimens. ${ }^{1,8,14,15}$

In addition to the explanations above, the negative results of the rapid molecular test using Xpert MTB/RIF were presumed to be greatly influenced by the collection, processing, and storage of specimens. Similarly, the results of Xpert MTB/RIF can vary, depending on the ability of laboratory personnel in compliance with work protocols. Rapid molecular test using Xpert MTB/RIF device requires the availability of a stable and uninterruptible power source during specimen testing. The temperature it required for specimen testing is $15-30^{\circ} \mathrm{C}$, while high ambient temperatures can increase the possibility of failures and cause damage to the components. Therefore, the rapid molecular testusing Xpert MTB/RIF must be carried out together with the MTB culture to avoid the risk of false-negative results and to obtain MTB isolates as material for identification and sensitivity testing. ${ }^{18,17}$

Table 3 shows 32 (54.2\%) results of "MTB not detected" in TB-HIV groups, suggesting a possible influence of the degree of immunosuppression of HIV to the clinical symptoms of TB, in addition to the difficulty of coughing up sputum as the most common reason of this. In people with HIV, the number and function of CD4 cells decrease progressively, as well as disruption in the function of macrophages and monocytes. The CD4 and macrophages are components that have a major role in the body's defense against mycobacteria. 13,15,19-21

The lower immunity will lead to negative results of bacterial culture due to poor or no formation of granulomas. Approximately $25 \%$ of HIV patients 
were not diagnosed with active $\mathrm{TB}$; therefore, $\mathrm{TB}$ screening was recommended for all HIV patients. $^{17,19,21,22}$

Rapid molecular test using Xpert MTB / RIF in this study gave greater results (42.4\%) of "MTB detected; Rif sensitive" in the TB-HIV group. This was likely due to NAAT-PCR based detection methods used by the deviceto qualitatively detect Deoxyribonucleic acid (DNA) of viable or non-viable MTB complex directly from sputum or non-sputum specimens. In addition, the minimum number of bacilli that can be detected by rapid molecular testusing Xpert MTB/RIF is 131 colony-forming units per $\mathrm{mL}$ of sputum. ${ }^{1,8}$

Pulmonary TB occurs when the immune system declines. From the epidemiological perspective, disease results from complex interactions. From the host point of view, susceptibility to MTB infection is strongly influenced by one's immune system at that time. People with HIV/AIDS or people with poor nutritional status are more susceptible to get infected with and suffer from TB. ${ }^{4}$

The World Health Organization defines high burden countries $(H B C)$ for $T B$ based on three indicators as follows: TB, TB-HIV, and MDR-TB. Cases of TB-HIV co-infection in 2010-2017 were recorded following the cohort of the previous year. The percentage of TB patients who were later diagnosed with HIV co-infection increased by 2,393 to 7,796 from 2009 to $2017 .{ }^{4}$

Rapid molecular test using Xpert MTB/RIF can detect $100-1000$ microorganisms/mL of sputum; therefore, the test on HIV-TB patients with sample size of 102-103 MTB can give results of "MTB detected; Rif sensitive" . This was in line with 27 studies by Steingart et al. on the performance of Xpert MTB/RIF which found that Xpert MTB/RIF had a sensitivity of $79 \%$ and a specificity of $92 \%-100 \%$ among HIV patients. In addition, WHO recommends that Xpert MTB/RIF is used as an initial diagnostic test

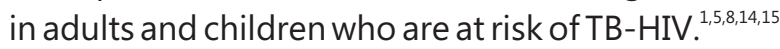

Rapid molecular tests using Xpert MTB/RIF showed 20 (3.8\%) results of "MTB detected, Rif resistance" in non-HIV-TB patients. Positive results of Rifampicin MTB resistance indicate that MTB bacteria possibly have a high resistance to Rifampicin. Rifampicin resistance is associated with mutations in the rpoB gene, which is encoded in the RNA polymerase $\beta$-subunit in MTB. ${ }^{23}$ This occurs when patients are infected directly from MDR TB patients or patients with previous incomplete and irregular TB treatment, not in accordance with treatment standards. ${ }^{1,8,23,24}$

Because this study was retrospective research merely using secondary data, the profile of patients was limited and some data were incomplete. In addition, further history of the initial process diagnosis, previous TB infection, and anti-TB treatment were not evaluated in this study. In the TB-HIV group further informations about the stage of HIV, the results of CD4 cell counts, history of TB diagnosis and previous administration of anti-TB drugs were needed. Variability of the results in this study were possibly due to differences in the severity of HIV and comorbidity in the patients involved.

\section{CONCLUSIONS AND SUGGESTIONS}

Rapid molecular test using Xpert MTB/RIF showed remarkably higher results of "MTB not detected" in pediatric and adult TB patients, suggesting a possible influence of multifactorial factors including a higher number of sample population of adult TB patients. The higher results of "MTB not detected" , "MTB detected; Rif sensitive", and "MTB detected; Rif resistant" were found in the TB non-TB-HIV group, HIV-TB group, and non-HIV TB group, respectively.

Based on these results, further research was recommended to determine and compare diagnostic value between the rapid molecular test using Xpert MTB/RIF, the microscopic examination of Acid-Fast Bacilli, and the MTB culture using a cohort method.

\section{REFERENCES}

1. Kementerian Kesehatan Republik Indonesia. Direktorat Jenderal Pengendalian Penyakit dan Penyehatan Lingkungan. Petunjuk teknis pemeriksaan TB menggunakan tes cepat molekuler. Jakarta, Kementerian Kesehatan RI, 2017; 1-3.

2. Kementerian Kesehatan Republik Indonesia. Peraturan Menteri Kesehatan Republik Indonesia No. 67 Tahun 2016 tentang penanggulangan tuberkulosis. Jakarta, Kementerian Kesehatan RI, 2016; 60-79.

3. Kementerian Kesehatan Republik Indonesia. Rakerkesnas 2018, Kemenkes percepat atasi 3 masalah kesehatan. Jakarta, Kemenkes, 2018. Cited on October $20^{\text {th }}$ 2019. Available from https://www. depkes.go.id/article/view/18030700005/rakerkesnas -2018-kemenkes-percepat-atasi-3-masalah -kesehatan.html

4. Kementrian Kesehatan Republik Indonesia. Tuberkulosis. Pusat data dan informasi Kementrian Kesehatan Republik Indonesia. Jakarta, Kementrian Kesehatan Republik Indonesia, 2018. Cited on 
October 15th 2019. Available from https://pusdatin. kemkes.go.id/pdf.php?id=18101500001.

5. World Health Organization. Policy update: Automated realtime nucleic acid amplification technology for rapid and simultaneous detection of tuberculosis and rifampicin resistance: Xpert MTB/RIF assay for the diagnosis of pulmonary and extrapulmonary TB in adults and children. Geneva, WHO, 2013; 10-73.

6. Haris A, Maher D, Graham S. TB-HIV a clinical manual. $2^{\text {nd }}$ Ed., Geneva, WHO Library Publishing, 2004; 23-59.

7. World Health Organization. Global tuberculosis report 2017. Geneva, WHO,2017; 1-5.Cited on September $19^{\text {th }}$ 2018. Available form: https://www.who.int/tb/ publications/global_report/gtbr2017_main_text.pdf

8. WHO. Xpert MTB/RIF implementation manual: Technical and operational 'How-to'; Practical considerations. Geneva, WHO, 2014; Cited on September $1^{\text {st }} 2018$. Available from: https://aidsfree. usaid.gov/sites/default/files/xpert_mtbrif_manual.pdf

9. Moussa Husseiny Sh, Bayoumi FS, Ali AM. Evaluation of GeneXpert MTB/RIF assay for diagnosis of pulmonary tuberculosis. Saudi Medical Journal, 2016t; 37(10): 1076-1081.

10. Pantoja A, Fitzpatrick C, Vassall A, Weyer K, Floyd K. Xpert MTB/RIF for diagnosis of tuberculosis and drugresistant tuberculosis: A cost and affordability analysis. Global TB programme, World Health Organization, Geneva, Switzerland. Eur Respir J, 2013; 42: 708-720.

11. Kementerian Kesehatan Republik Indonesia. Direktorat Jenderal Pengendalian Penyakit dan Penyehatan Lingkungan. Petunjuk teknis manajemen dan tatalaksana TB anak. Jakarta, Kementerian Kesehatan RI, 2016; 3-18.

12. Marais BJ, Pai M. Recent advances in the diagnosis of childhood tuberculosis. Dis Child, 2007; 92(5): 446-52.

13. Detjen $A K$, Dinardo $A R$, Leyden J, Steingart $K R$, Menzies D, Schiller I, Mandalakas AM. Xpert MTB/RIF assay for the diagnosis of pulmonary tuberculosis in children: A systematic review and meta-analysis. The Lancet Respiratory Medicine, 2015; 3(6): 451-461.

14. Helb D, Jones M, Story E, Boehme C, Wallace E, Ho K, et al. Rapid detection of Mycobacterium tuberculosis and rifampin resistance by use of on-demand, near-patient technology. J Clin Microbiol, 2010; 48(1):229-237.

15. Blakemore R, Story E, Helb D, Kop J, Banada P, Owens $M R$, et al. Evaluation of the analytical performance of the Xpert MTB/RIF assay. J Clin Microbiol, 2010; 48(7):2495-2501.

16. Mandell G, Bennett J, Dolin R. Mandell, Douglas, and Bennett's principles and practice of infectious diseases. Philadelphia, Churchill Livingstone/Elsevier, 2010; 3129-3130.

17. Kementerian Kesehatan Republik Indonesia. Direktorat Jenderal Pengendalian Penyakit dan Penyehatan Lingkungan. Pedoman nasional pengendalian tuberkulosis. Jakarta, Kementerian Kesehatan RI, 2014; 1-21.

18. Dinnes J, Deeks J, Kunst H, Gibson A, Cummins E, Waugh $\mathrm{N}$, et al. A systematic review of rapid diagnostic tests for the detection of tuberculosis infection. Health Technol Assess, 2007;11:1-96.

19. Mulyadi, Yenny Fitrika. Hubungan tuberkulosis dengan HIV/AIDS. Idea Nursing Journal,2010; 2(2): 163-166.

20. Montales MT, Beebe A, Chaudhury A, Patil N. Mycobacterium tuberculosis infection in an HIVpositive patient. Respir Med Case Rep, 2015; 16: 160-162.

21. Kementerian Kesehatan Republik Indonesia. Direktorat Jenderal Pengendalian Penyakit dan Penyehatan Lingkungan. Petunjuk teknis tata laksana klinis ko-infeksi TB-HIV. Jakarta, Kementerian Kesehatan RI, 2012; 14-26.

22. Padmapriyadarsini $C$, Narendran G, Swaminathan S. Diagnosis andtreatment of tuberculosis in HIV co-infected patients. The Indian Journal of Medical Research, 2011; 134(6): 850-865.

23. Li J, Xin J, Zhang L, Jiang L, Cao H, Li L. Rapid detection of rpoB in rifampin resistant $M$, tuberculosis from sputum samples by denaturing gradient gel electrophoresis. Int J Med Sci, 2012;9(2):148-156.

24. Kementerian Kesehatan RI. Direktorat Jenderal Pengendalian Penyakit dan Penyehatan Lingkungan. Buku saku pasien TB MDR. Jakarta, Kementerian Kesehatan RI, 2015; 3-8. 